Syntax Fusion : Jurnal Nasional Indonesia

P-ISSN: $x x x x-x x x x$

E-ISSN : $\mathrm{xxxx}-\mathrm{xxxx}$

Vol. 1, No. 2, Februari 2021

\title{
KONFLIK INTERNAL ANTARA PEMERINTAH INDONESIA DENGAN GERAKAN SEPARATIS DI PAPUA
}

\author{
Indah Putri Mardiani, Ismi Anisah, Marlina Hasibuan, Nur Fadilah \\ Universitas Islam Negeri Sultan Syarif Kasim
}

E-mail: 12010224638@ @students.uin-suska.ac.id, 12010221029@students.uin-suska.ac.id, 12010221034@students.uin-suska.ac.id, 12010221002@students.uin-suska.ac.id

\section{Abstrak}

Tujuan dari artikel ini adalah untuk mengetahui Propaganda Gerakan Papua Merdeka yang dilaksanakan oleh Organisasi Papua Merdeka (OPM) melalui media cetak dan online menjadikan pesan-pesan OPM menyebar dengan cepat dan luas ke tengah-tengah masyarakat global, sehingga OPM cenderung mendapat perhatian dan dukungan dari dunia Internasional. Setelah terjadinya penyerangan kepada warga sipil oleh salah satu faksi OPM di Kabupaten Nduga, Papua, berbagai media, salah satunya portal utama media online OPM, freewestpapua.org, memberitakan kasus tersebut sesuai dengan perspektif masing-masing. Oleh karena gerakan OPM bertentangan dengan prinsip Negara Kesatuan Republik Indonesia, itu menjadi penting untuk kita mengetahui bagaimana OPM mencitrakan Pemerintah Indonesia dalam berita mengenai kasus tersebut. Setelah dilakukan analisis wacana kritis model Van Dijk terhadap teks berita yang dipilih secara purposif dari situs web freewestpapua.org, disimpulkan bahwa baik dalam struktur teks Makro, Superstruktur, maupun Mikro, meskipun pelaku penyerangan warga sipil adalah OPM sendiri, dan korbannya bukan orang Papua, situs propaganda online OPM, tetap mencitrakan Indonesia sebagai penjajah yang sadis, brutal, licik, dan biadab. Metode penelitian yang digunakan penulis adalah metode penelitian kualitatif yang dilandaskan oleh Teori dan penjelasan. Guna dari dipilihnya metode ini adalah untuk menilai terhadap bagaimana kondisi obyek yang alami.

Kata Kunci: Konflik, Organisasi Papua Merdeka, Pemerintah

\section{Pendahuluan}

Pada saat kemerdekaan Indonesia, Pemerintahan Belanda telah mempersiapkan pemerintahan bagi Papua untuk memisahkan diri dari Belanda dan Indonesia, termasuk pembentukan badan legislatif, bendera, dan lagu kebangsaan untuk Papua. Namun Pemerintah Indonesia menyatakan bahwa wilayah Papua masuk ke dalam wilayah Negara Kesatuan Republik Indonesia pada perjanjian New York pada tahun 1962, tanpa melibatkan satupun masyarakat Papua.

Golongan terpelajar Papua pada tahun 1964 mengusahakan kebebasan Papua untuk memilih agar lepas dari Indonesia dan Belanda ke Perserikatan Bangsa Bangsa. Kemudian upaya separatisme berkembang hingga lebih terstruktur dan mereka membentu suatu organisasi 
yaitu Organisasi Papua Merdeka (OPM). OPM berusaha untuk meningkatkan kesadaran dan dukungan dari masyarakat dunia akan usaha untuk kemerdekaan Papua dengan pembagian kerja yang terdiri dari kelompok bersenjata yang beroperasi di tiga wilayah yang berbeda, kelompok yang melaksanakan aksi protes dan demonstrasi, dan kelompok yang berbasis di luar negeri. Dikutip dari artikrl BBC Indonesia, perlawanan bersenjata beberapa kali dilincurkan OPM terhadap masyarakat sipil pendatang dari luar Papua, mulai dilakukan pada tanggal 26 Juli 196 di Manokwari, dan pada tahun 2018 terjadi beberapa kali penembakan terhadap pekerja proyek Trans Papua, pekerja PT Istaka Karya, dan anggota Brimob, serta yang terkhir penyekapan terhadap guru dan tenaga medis yang bertugas disana.

Sampai saat ini, telah banyak upaya penyelesaian yang dilakukan oleh pemerintah Indonesia terhadap konflik yang terjadi, mulai dari tindakan represif maupun militeristik hingga non-represif seperti pemberlakuan Undang - Undang Republik Indonesia Nomor 21 Tahun 2001 Tentang Otonomi Khusus Bagi Proinsi Papua. Akan tetapi hal itu belum dapat terealisasikan.

Beberapa penelitian dan temuan sebelumnya telah berkontribusi pada pengetehuan tentang konflik di Papua diantaranya adaalah Sugiyanto (2007) dan Sefriani (2003)dengan pendekatan hukum Internasional, juga Sugandi (2008) dengan pendekatan lembaga Internasional sebagai mekanisme penyelesaian konflik. Suratman (201) menunjukkan bahwa gerakan separatime yang dilakukan oleh warga papua menjadi salah satu indikator terjadinya proxy war di Indonesia yang hingga sampai saat ini belum dapat terselesaikan. Kajian yang dilakukan oleh Hadi (2016) mengungkapkan pejuanga kemerdekaan Papua hingga saat ini sudah menggunakan aksi-aksi non-iolent melalui penggunaan teknologi dan media propaganda untuk mencapai tujuan politik kelompoknya, yaitu menggalang dukungan sampai ke lingkup Internasional.

Studi lainnya yaitu dalam tulisan Istikharah (2017), pengarahan negasiator untuk melakukan dialog dalam diplomasi Pemerintah Indonesia untuk membebaskan warga negara Indonesia (WNI) sandera kelompok Abu Sayyaf menunjukkan adanya tanda keberhasilan. Penanganan konflik separatisme berlatarbelakang etnis dan agama Bangsa Moro yang terjadi di filifina yang awalnya represif dan kemudian berubah menjadi mengarah pada negosiasi yang menghasilkan perjanjian yang disetujui oleh pihak Bangsa Moro dan Filipina. Hingga saat ini konflik OPM belum juga menemukan titik penyelesaian. TPNBP-OPM atau Tentara Pembebasan Nasional Papua Barat-Organisasi Papua Merdeka masih terus menyuarakan kepentingannya untuk 'merdeka' dari Indonesia serta mengajukan tuntutan terhadap Pemerintah Indonesia. Sampai sejauh ini tuntutan mereka belum juga terpenuhi, mereka mengancam bahwa perang diantara mereka dengan Pemerintah Indonesia tidak akan berhenti.

Peter Wallensten (201) mengemukakan ada tujuh mekanisme resolusi konflik. Pertama yaitu suatu pihak mengubah tujuan dengan mengubah prioritas, kedua adalah para pihak yang adalah pihak yang mengubah tujuan mereka dengan berusaha menemukan titik dimana sumber daya dapat dibagi, ketiga adalah horse-trading, keempat adalah shared control, kelima adalah menyerahkan kontrol ke pihak lain, keenam adalah arbitrasi atau jalur hukum, dan yang terakhir adalah meninggalkan konflik begitu saja sampai terlupakan. Artikel ini membahas resolusi konfikhorse-trading. Mekanisme horse-trading dilakukan dengan berkompromi antara kedua belah pihak, dimana pihak yang memiliki konflik mendapatkan apa yang mereka inginkan dengan syarat semua tuntutan dan tujuan pihak yang lain harus terpenuhi. Mekanisme 
penyelesaian konflik ini menghasilkan keputusan yang baru setelah kedua belah pihak berkomunikasi untuk mencari jalan keluar bersama-sama, dengan kondisi kedua belah pihak dapat mengesampingkan egonya masing-masing.

\section{Metode Penelitian}

Metode penelitian yang digunakan penulis adalah metode penelitian kualitatif yang dilandaskan oleh Teori dan penjelasan. Guna dari dipilihnya metode ini adalah untuk menilai terhadap bagaimana kondisi obyek yang alami, analisis data yang bersifat kualitatif dan induktif serta hasil penelitian yang lebih menekankan arti dibanding dengan generalisasi perkembangan penelitian pada metode ini masih biasa dilakukan selama proses penelitian berlangsung, sama halnya dengan analisis data juga dapat dilakukan selama proses berlangsung.

Cara memandang fakta pada penelitian ini adalah berpatok pada penelitian yang menginterpretasi data selanjutnya dijelaskan oleh berbagai macam teori yang dianggap relevan, untuk menghasilkan suatu teori serta menguatkan teori yang sudah ada. Prosedur pengumpulan data pada penelitian ini yaitu dengan memilih teori dari para narasumber yang mampu memberikan informasi yang spesifik.

\section{Pembahasan}

\section{Sejarah Berdirinya OPM}

Terbentuknya OPM ( organisasi papua merdeka ) dilandasi dari berbagai masalah yang berasasl dari pemerintah Indonesia, pusatnya pada masalah politik. Seluruh penduduk asli papua berasumsi bahwa pemerintah pusat berbalik badan dalam pembangunan kesejahteraan dan pembangunan ekonomi rakyat papua. Hal-hal yang menyebabkan munculnya OPM adalah ketidakmampuan Negara dalam penyeimbangan kebijakan politik tehadap kepentingan masyarakat papua. Maka dari itu rakyat papua melakukan tindakan untuk mencari keadilan atas semua bentuk perlakuan ketidakadilan pemerintah pusat terhadap papua. Menangih serta menuntut segala janji yang dilandasi oleh kebijakan yang adil kepada seluruh rakyat Indonesia yang merupakan suatu hal yang harus dejalankan oleh Negara tapi, tak segala bentuk keadilan tersebut berlaku kepada papua. Impian rakyat papua hanyalah menjadi daerah yang sejahtera serta makmur dengan segala sumber daya alam yang dimilikinya, namun semua itu hanyalah sebagai hiasan yang menempel layaknya seperti pajangan belaka. Wajar saja gerakan separatis muncul yang diakibatkan oleh kelalaian Negara dalam memberikan perhatian serta keadilan.

Berdirinya Organisasi Papua Merdeka sebagai gerakan separatis pada tahun 1965 yang memiliki tujuan mewujudkan kemerdekaan rakyat papua dari bagian barat dari Negara Indonesia. Papua dan papua barat dulunya pada masa sebelum era reformasi dipanggil dengan sebutan irian jaya. Hubungan sejarah papua dengan bagian Indonesia ataupun asia tidak dianngap memiliki hubungan oleh papua sebab kisah penyatuan papua kdalam Negara Kesatuan Rakyat Indonesia terjadi akibat perjanjian belanda dengan Indonesia bahwa belanda menyerahkan yang dikuasai belanda yaitu Papua terhadap bekas jajahannya yang merdeka, tidak lain yaitu Indonesia. OPM menganggap perjanjian itu hanyalah pindah tangan dari penjajah Belanda kepada penjajah Indonesia. 
Ada beberapa aspek yang menjadi penyebab pemberontakan Oganisasi Papua Merdeka yaitu sebagai berikut : pertama. Aspek Politik, janji dari pemerintah belanda untuk mendirikan suatu negar (boneka) papua setelah lepas dari negara Indonesia terjadi pada pemerintahan belanda. Sebagian dari putra daerah yang pro terhadap belanda berharap akan kedudukan yang sesuai di Negara papua tersebut, namun janji tersebut tak dapat direalisis karena irian jaya ( nama setelah papua dan papua barat dipisah dar belanda) mesti diserahkan kepada Indonesia untuk memenuhi perjanjian yang telah dibuat. Walaupun dalam isi perjanjian tersebut terdapat pasal mengenai hak untuk menentukan nasib sendiri, tapi kenyataannya papua sebagai buah perjanjian harus diserahkan kepada Indonesia dan disaksikan oleh pejabar PBB. Dua poin penjelasan dari aspek politik ini (1). Harapan akan lahirnya kemerdekaan (2).penyalahgunaan penentuan pendapat rajyat ( pepera).

Kedua.Aspek ekonomi, Inilah salah satu dari beberapa penyebab pemberontakan OPM. Kemerosotan ekonomi di Indonesia yang sangat buruk pada tahun 1964-1966 menyebabkan kemacetan penyaluran sandang dan pangan masyarakat papua. Serta serta tindakan para petugas Indonesia yang memborong kebutuhan pangan yang ada di took lalu mendagangkannya ke daerah luar Papua demia memperkaya diri sendiri. Mengakibatkan kekurangan sandang dan pangan masyarakat papua. Padahal kondisi kekurangan bahan sandang dan pangan tak pernah dialami masyarakat papua selama penjajahan pemerintahan Belanda.

Ketiga. Aspek psikoligis, pemikiran yang hanya dikendalikan dengan emosi menjadikan ini sebagai salah satu penyebab pemberontakan OPM. Pendidikan yang masih kurang dan bahkan tidak ada bagi rakyat pedalaman dan pesisir pantai menjadikan mereka mudah terpengaruhi, mudah terbawa emosi dibandingkan dengan memikirkannya suatu masalah secara kritis. Begitu juga dalam pengendalian sikap yang ceroboh apabila ada suatu janji yang tidak ditepati. Semuanya sangat wajar karena warga papua yang mendapatkan pendidikan hanyalah mereka yang tinggal diperkotaan.

Keempat. Aspek sosial, perbedaan pengangkatan pejabat pemerintah lokal pada masa belanda, dimana pengangkatan pejabat irian jaya yang diambil dari kepala suku berbeda dengan daerah jawa yang mengangkat pejabat dai kalangan priyayi. Yang menyebaban jika ada yang memberontak maka akan berpengaruh kepada suku serta dalam keadadan yang menghawatirkan kepala suku harus berada pada titik tengah. Banyaknya masayarakat yang terpinggirkan dan marjinalisasi pada masyarakat papua yang biasanya menjadi masalah sebagai dasar perbandingan kemakmuran dan kesejahteraan.

Kelima. Aspek ideologis, hidupnya suatu kepercayaan dikalangan rakyat papua tentang kepercayaan seorang pemimpin besar sebagai ratu adil yang mampu menjadikan hidup lebih baik dan makmur adalah salah satu penyebab terjadinya pemberontakan Organisasi Papua Merdeka.

\section{Konflik Internal Antara Pemerintah Dan OPM}

Beberapa aspek yang menjadi penyebab pemberontakan Oganisasi Papua Merdeka yaitu. Dilangsir dari penelitian Djopari(1991)3 , di tahun 1963-1964 menjadi perpecahan faksi militer organisasi papua mereka yang diakibatkan oleh perbedaan orientasi politik danya perbedaan orientasi politik pro-Barat dan orientasi neo-marxis atau sosialis oleh 
pemimpin politik OPM. Lain halnya, sebelum OPM membentuk organisasi separatis, Organisasi Papua merdeka dimulai dengan seragan bersenjata, perusakan, penyanderaan, demonstrasi dan pengibaran bendera Papua Barat oleh suku Arfak di Manokwari dan akhirnya menyebar ke beberapa kabupaten yang ada di Irian Jaya. Pecahnya militer disebabkan oleh militer OPM yang mulai lemah mengakibatkan tumpasnya aksi pemberontakan papua yang dibasmi oleh Pemerintah Indonesia yang mengutus Angkatan Bersenjata Republik Indonesia (ABRI).

Maka saat itu, Pemerintah pusat berpendapat bahwa tindakan OPM termasuk kedalam upaya separatisme yang melanggar hukum dan kedaulatan Indonesia, sehingga Pemerintah pusat akhirnya melakukan perlawanan . Berbagai macam bentuk tindakan yang dikerahkan sebagai upaya separatisme diatur dalam berlangsungnya penyerangan bersenjata antara ABRI dan OPM yang mengakibatkan bertambahnya korban jiwa dari kedua belah puhak.

Maka mulai disadarinya masalah kesenjangan sejarah, masalah kesejahteraan, serta masalah identitas masyarakat Papua yang membawa Pemerintah Indonesia pada 19711973 sama halnya dalam penanganan lanjutan kepada beberapa konflik yang dilakukan dengan cara selain militeristik yakni upaya nasionalisasi terhadap aspek budaya, sosial, ekonomi dan politik, juga meninggalkan aspek-aspek asli mereka dengan tujuan menciptakan masyarakatsesuai dengan pengamalan Pancasila dan UUD 1945, yakni adil dan makmur. Namun upaya ini justru seakan membangun persepsi dari masyarakat Papua bahwa identitas dari budaya mereka tidak beradab dan terbelakang oleh Indonesia, sehingga semakin memicu anggapan kesenjangan budaya mereka dari Indonesia.

\section{Resolusi Konflik Sebelumnya Dalam Menyelesaikan Konflik Indonesia - OPM}

Konflik OPM sebenarnya diawali dari konflik antara kelompok di dalam organisasi OPM dan konflik OPM dengan kelompok masyarakat yang ada di Papua sendiri. Oleh karena itu, pada masa awal munculnya pemberontakan, pihak Pemerintah Indonesia bertindak sebagai pihak ketiga yang menangani konflik antara kelompok-kelompok tersebut. Menurut penelitian Djopari (1991), pada tahun 1963 dan 1964 terdapat perpecahan dalam faksi militer OPM akibat adanya perbedaan orientasi politik pro-Barat dan orientasi neo-marxis atau sosialis dari pemimpin politik OPM. Selain itu, sebelum OPM berkembang menjadi organisasi separatis, gerakan OPM diawali dengan penyerangan bersenjata, perusakan, penyanderaan, demonstrasi dan pengibaran bendera Papua Barat oleh suku Arfak di Manokwari dan selanjutnya meluas ke berbagai kabupaten di Irian Jaya. Perpecahan militer menyebabkan militer OPM melemah sehingga aksi pemberontakan mereka berhasil ditumpas oleh Pemerintah Indonesia yang pada saat itu dilakukan oleh Angkatan Bersenjata Republik Indonesia (ABRI).

Pada saat itu, Pemerintah Indonesia menganggap tindakan OPM sebagai upaya separatisme yang melanggar hukum dan kedaulatan Indonesia, sehingga Pemerintah Indonesia merasa berhak melakukan perlawanan senjata. Berbagai tindakan yang dilakukan sebagai upaya separatisme diatur dalam Bab I Buku Kedua: Kejahatan Kitab Undang-Undang Hukum Pidana, dimana tindakan pemberontakan tersebut menurut Pasal 108 ternasuk kejahatan terhadap keamanan negara, dan gerakan separatis menurut Pasal 106 tergolong upaya makar. Upaya penyerangan bersenjata antara ABRI dan OPM ini 
semakin menambah korban jiwa.

Selanjutnya mulai disadari akan masalah kesenjangan sejarah, masalah kesejahteraan, serta masalah identitas masyarakat Papua yang selanjutnya membawa Pemerintah Indonesia pada 1971-1973 dalam penanganan lanjutan terhadap konflik ini dilakukan dengan cara selain militeristik yakni upaya nasionalisasi terhadap aspek budaya, sosial, ekonomi dan politik, serta meninggalkan aspek-aspek asli mereka dengan tujuan menciptakan masyarakat sesuai dengan pengamalan Pancasila dan UUD 1945, yakni adil dan makmur. Namun upaya ini justru seakan membangun persepsi dari masyarakat Papua bahwa identitas dari budaya mereka tidak beradab dan terbelakang oleh Indonesia, sehingga semakin memicu anggapan kesenjangan budaya mereka dari Indonesia (Sugandi, 2008).

Hingga pada tahun 1999 Pemerintah Indonesia melakukan pemekaran Irian Jaya lewat Undang-Undang RI nomor 45 tahun 1999 oleh Presiden Habibie dengan pembentukan Provinsi Irian Jaya Barat, Provinsi Irian Jaya Tengah, Kabupaten Kabupaten Mimika, Kabupaten Puncak Jaya, dan Kota Sorong. Pemekaran tersebut dilakukan untuk melakukan peningkatan penyelenggaraan pemerintahan serta pembinaan masyarakat di daerah tersebut sehingga memudahkan penguatan integrasi Papua sebagai bagian dari Negara Kesatuan Republik Indonesia. Namun kembali terjadi lagi, masyarakat Papua menolak kebijakan ini karena mereka menilai bahwa dalam pengambilan kebijakan ini tidak melibatkan suara dari masyarakat Papua.

Penolakan ini selanjutnya mendorong pembentukan otonomi daerah Papua, dimana lewat Ketetapan MPR Nomor IV/MPR/1999 dibahas suatu kerangka otonomi yang berusaha memenuhi tuntutan masyarakat Papua, yakni untuk menghargai perbedaan kebudayaan dan kehidupan sosial masyarakat Papua. Dengan mulai menindaklanjuti tuntutan atas perbedaan di aspek-aspek tersebut, akhirnya disahkan Undang-Undang Nomor 21 Tahun 2001 tentang Otonomi Khusus untuk Provinsi Papua.

Kebijakan ini memberikan kesempatan kepada masyarakat Papua untuk membangun penyelenggaraan pemerintahan wilayahnya serta meningkatkan kesejahteraan masyarakatnya sesuai dengan kewajiban dan hak warga negara Indonesia, dengan tetap menghargai nilai-nilai dasar penduduk asli Papua. Kebijakan ini juga mengembalikan nama Irian Jaya kembali menjadi Papua. Pemerintah Indonesia menaruh harapan besar dalam pemberlakuan kebijakan ini, termasuk sebagai upaya meredam tindakan OPM. Namun, dalam pelaksanaan dan dukungan dari berbagai institusi pemerintah terkait juga belum efektif.

Termasuk persilangan kebijakan tersebut dengan kebijakan nasional lainnya yang justru menghambat pencapaian Otonomi Khusus (Otsus), salah satunya ialah program transmigrasi ke Papua. Ditambah dengan dilema pasca Otsus antara mendukung Otsus atau merdeka sepenuhnya dari Indonesia, juga ketidakamanan dari implementasi Otsus sendiri, karena ketidakpercayaan dan pesimistik dari masyarakat Papua terhadap penyelenggara Negara (Kementerian Koordinator Bidang Politik, Hukum, dan Keamanan Republik Indonesia, 2016). Selain itu, terdapat kebijakan pemerintah pusat yang kontraproduktif dengan tuntutan atau harapan masyarakat Papua, salah satu diantaranya yaitu program transmigrasi yang ditolak masyarakat asli Papua dan berdampak pada merebaknya konflik horizontal. Program transmigrasi ke Papua pada akhirnya dihentikan 
pemerintah pada tahun 2000 (Kompas.com, 2015).

Berbagai upaya pemerintah belum juga menunjukkan keberhasilan dalam menangani konflik ini. Sampai pada aksi bersenjata pada 2018 ini, pemerintah Indonesia lewat TNI dan POLRI masih harus mengerahkan pasukan untuk menangani penyerangan yang dilakukan terhadap masyarakat sipil dan polisi di Papua. Pada tahun 2000-an, selain upaya militeristik yang masih dilakukan, pemerintah juga kembali memperhatikan aspek-aspek ekonomi, pendidikan, kesehatan, sosial budaya, serta politik dari Papua yang masih kurang dari optimal. Berdasarkan penelitian dari Lembaga Il,mu Pengetahuan Indonesia (LIPI) tahun 2008, pemerintah mulai fokus pada pembangunan konektivitas infrastruktur sebagai upaya pemenuhan HAM dan aspek-aspek lainnya (Kedeputian Bidang Ilmu Pengetahuan Sosial dan Kemanusiaan, LIPI, 2008).

Dalam jalannya konflik ini, pihak eksternal turut terlibat. OPM yang berbasis di Pasifik, Amerika Serikat dan Eropa berusaha menggalang dukungan dari masyarakat internasional untuk kemerdekaannya (BBC News Indonesia, 2018). Gerakan dari faksi militer, ULMWP (United Liberation Movement for West Papua) dari OPM juga mengajukan petisi ke PBB dengan tujuan dapat masuk daftar Komite Dekolonisasi PBB kembali. Petisi tersebut ditandatangani oleh 1,8 juta orang dengan persentase $95,77 \%$ berasal dari warga asli Papua Barat (Institute for Policy of Conflict, 2015). Pengajuan kepada PBB ini dibantu oleh negara Vanuatu, sebagai anggota MSG (Melanesian Spearhead Group) juga menggalang dukungan dari negara-negara MSG lainnya dengan menekankan nilai penegakkan HAM dan demokrasi (Gumilang, 2019).

Menghadapi dukungan eksternal terhadap OPM, Pemerintah Indonesia teguh pada posisinya sebagai negara yang berdaulat. Dengan status OPM sebagai pemberontak yang kedudukannya di bawah pemerintah Indonesia, tidak ada pihak manapun yang berhak mengintervensi mempengaruhi konflik antara OPM dengan Pemerintah Indonesia ataupun membawanya ke peradilan internasional tanpa keterlibatan pihak Pemerintah Indonesia sendiri. Pemerintah Indonesia mengambil tindakan yang tegas. Wakil Presiden Jusuf Kalla dalam sesi debat umum Sidang Majelis Umum ke-73 PBB menyatakan bahwa tindakan Vanuatu melanggar prinsip-prinsip PBB karena tidak menghormati kedaulatan dan integritas teritorial. Ia juga menyatakan bahwa Indonesia tidak akan tinggal diam dalam membela integritas teritorial Indonesia (Kompas.com, 2018).

Pada Juli 2019, upaya tokoh OPM di Inggris, Benny Wenda, berhasil mendapatkan pengakuan Dewan Kota Oxford, Inggris, yang memberikan penghargaan „Freedom of Oxord ${ }^{\text {te }}$ kepada Benny Wenda. Pemerintah Indonesia melalui Kementerian Luar Negeri dalam menanggapi hal ini menyatakan kecaman keras, dan menganggap ketidakpahaman pemberi penghargaan, dilihat dari sepak terjang Benny Wenda sebagai tokoh separatis. Dukungan Dewan Kota Oxford ini dianggap Pemerintah Indonesia tidak bermakna apapun mengingat Pemerintah Inggris selama ini konsisten untuk mendukung kedaulatan dan integritas Negara Kesatuan Republik Indonesia (Sekretariat Kabinet Republik Indonesia, 2019).

\section{Simpulan}

Berdirinya Organisasi Papua Merdeka sebagai gerakan separatis pada tahun 1965 yang 
memiliki tujuan mewujudkan kemerdekaan rakyat papua dari bagian barat dari Negara Indonesia. Papua dan papua barat dulunya pada masa sebelum era reformasi dipanggil dengan sebutan irian jaya. Hubungan sejarah papua dengan bagian Indonesia ataupun asia tidak dianngap memiliki hubungan oleh papua sebab kisah penyatuan papua kdalam Negara Kesatuan Rakyat Indonesia terjadi akibat perjanjian belanda dengan Indonesia bahwa belanda menyerahkan yang dikuasai belanda yaitu Papua terhadap bekas jajahannya yang merdeka, tidak lain yaitu Indonesia. OPM menganggap perjanjian itu hanyalah pindah tangan dari penjajah Belanda kepada penjajah Indonesia. beberapa aspek yang menjadi penyebab pemberontakan Oganisasi Papua Merdeka yaitu Aspek politik, aspek ekonomi, asapek psikologi, aspek sosial, aspek ideology. penanganan lanjutan kepada beberapa konflik yang dilakukan dengan cara selain militeristik yakni upaya nasionalisasi terhadap aspek budaya, sosial, ekonomi dan politik, juga meninggalkan aspek-aspek asli mereka dengan tujuan menciptakan masyarakat sesuai dengan pengamalan Pancasila dan UUD 1945, yakni adil dan makmur.

Konflik yang terjadi antara Pemerintah Indonesia dengan OPM adalah sebuah konflik dengan akar permasalahan kompleks, mulai dari permasalahan historis, ideologi, hingga rasa ketidakadilan yang diterima rakyat Papua. Perlawanan yang terjadi bukan hanya semata-mata karena ingin memerdekakan diri, namun juga dalam rangka memperjuangkan keadilan sosial dan ekonomi bagi masyarakat Papua. Resolusi konflik yang telah dilakukan oleh kedua belah pihak dianggap masih belum efektif. Penyelesaian konflik yang paling efektif untuk ditempuh adalah dengan melakukan dialog antara kedua belah pihak.

Untuk itu diharaokan konflik yang terjadi antara pemerintah Indonesia dan rakyat Papua dapat diselesaikan dengan baik. Sehingga provinsi Papua tetap menjadi bagian dari wilayah NKRI dan semoga pemerintah Indonesia lebih memperhatikan dan memberikan perhatian yang lebih terhadap masyarakat terutama dalam bidang pendidikan dan pembangunan. Sehingga mereka merasa lebih diperhatikan dan mendapatkan keadilan sebagai warga negara Indonesia.

\section{Bibliografi}

Sekar Wulan, Febrianti, dkk. 2019. Penyelesaian Konflik Internal antara Pemerintah Indonesia Dengan Gerakan Separatism di Papua Melalui Mekanisme Horse-Trading. Jawa barat: society.

Yulia Sugandi, 2008. Analisis konflik dan rekomendasi kebijakan mengenai papua, Jakarta [ID]: Freidrich Ebert Stilftung.

Nugroho, dkk. 2013. Kantor Perwakilan Organisasi Papua Mereka (OPM) di OxpordInggris: Babak Baru Separatisme Papua. Yogyakarta : Mire

Djopari, J.R.G.(Johanes Rudolf Gerzon) 1950-1993. Pemberontakan Organisassi Papua Merdeka. Library Holdings.

BBC News Indonesia. (2018, 12 13). Organisasi Papua Merdeka yang menuntut pemisahan Papua dari Indonesia, apa dan siapa mereka? Retrieved 4 26, 2019, from https://www.bbc.com: https://www.bbc.com/indonesia/indonesia-46539502

BBC News Indonesia. (2018, 11 22). Puluhan triliun dana otonomi khusus dialirkan, 
Konflik Internal Antara Pemerintah Indonesia Dengan Gerakan Separatis Di Papua

mengapa masih ada tuntutan 'Papua merdeka'? Retrieved 5 12, 2019, from https://www.bbc.com: https://www.bbc.com/indonesia/indonesia-46289211 